\title{
原子力配管用材料に対する多軸疲労パラメータの適用性の検討*
}

\author{
高橋 由 紀 夫*1

\section{Study on Applicability of Multiaxial Fatigue Parameters to Nuclear Piping Materials}

\author{
Yukio TAKAHASHI ${ }^{* 2}$ \\ ${ }^{* 2}$ Central Research Institute of Electric Power Industry, \\ 2-11-1 Iwadokita, Komae-shi, Tokyo, 201-8511 Japan
}

\begin{abstract}
Treatment of stress multiaxiality in the fatigue assessment is of practical importance for many components subjected to multiaxial cyclic loading during operation. Based on the results of multiaxial fatigue tests on hollow and solid bar speciments of SUS316NG and SGV410, accuracy of fatigue life prediction based on the conventional parameters as well as a two parameter approach proposed here was studied. The conventional parameters tended to provide conservative life prediction for the case of shear-dominated cases especially for $316 \mathrm{NG}$ while the new approach was able to give more realistic prediction.
\end{abstract}

Key Words: Fatigue, Multiaxial Fatigue, Austenitic Stainless Steel, Carbon Steel, Life Prediction

\section{1. 緒言}

繰返し荷重を受ける多くの機械や構造物では疲労に よるき裂発生や破損の可能性があることから，設計や 健全性評価においてその評価が重要になることが多 い. 原子力プラントの重要機器においても疲労評価は 設計基準や供用中検查基準の重要な部分を成してい

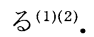

材料の疲労特性を把握するための疲労試験はほとん ぞ引張圧縮の単軸応力状態で実施されるが，一般に構 造物にはさまざまな多軸応力状態が発生し, 疲労評価 においてもこれを適切に処理することが重要である. 現在の原子力プラント機器や圧力容器に対する構造設 計基準では, 多軸応力状態を等価な単軸引張圧縮特性 に換算するために, 塑性理論に基づいた最大せん断応 力範囲や Mises の相当ひずみ範囲が用いられている が, 多軸疲労試験の結果を基にこれまでほかにも種々 のパラメータが提案されてきている(3) (6). しかし，こ れらの検討は比較的狭い条件での試験に基づいて行わ

\footnotetext{
* 原稿受付 2007 年 10 月 3 日.

*1 正員, フエロ-, (財)電力中央研究所材料科学研究所 (䩛 201-8511 狛江市岩戸北 2-11-1)

E-mail : yukio@criepi.denken.or.jp
}

れた場合が多く，それらの妥当性が低サイクル疲労か ら高サイクル疲労に至るまでの十分幅広い範囲で明ら かにされてきたとは言い難い。これらをかんがみて, 本研究では，原子力プラントに対する疲労評価法の有 効性の確認と高度化に資するため, 配管系に使用され ている 2 種の構造材料を対象に実施された幅広い多軸 疲労試験の結果を基に, 多軸疲労寿命評価法に関する 検討を行った。

\section{2. 試験材料および試験方法}

試験に用いられた材料はオーステナイト系ステンレ ス鋼 SUS316NG と炭素鋼 SGV410 の 2 種である.こ れらの化学成分を表 1 に示す. SUS316NG は耐応力 腐食割れ対策で低炭素化，窒素添加された材料であ る.疲労試験は中空，中実の丸棒試験片に対してすべ て室温で実施された。

試験条件と試験体数を表 2 に示す。さまざまな試験 が含まれているが, 試験片としては中空と中実の丸棒 試験片が用いられ, 後者は荷重制御のみであるが, 前 者の場合には荷重制御とひずみ制御の双方が含まれて いる. 荷重としては，軸力のみ，ねじりモーメントの み,これらの同位相または逆位相(円形経路)での重冨 のほか, 一定の軸力や曲げモーメントを負荷した状態 
でねじりモーメントの繰返しを与えるものも含まれて いる. 各材料計 50 本程度ずつで, 実測寿命は 500 サ イクル程度から $10^{7}$ サイクルでの未破断まで幅広い範 囲をカバーしている。

\section{3. 寿 命 評 価 法}

\section{$3 \cdot 1$ 評価法の概要 通常の疲労試験には直径 10} $\mathrm{mm}$ 程度の丸棒疲労試験片が使用されることが多く, ひずみ制御，荷重制御とも，延性材料では破損に至る 前に数ミリ程度の巨視き裂が発生しているのが普通で ある。また，巨視き裂に至る前には，寿命の長い範囲 にわたって微小き裂段階での進展があり,この過程も 破壊力学である程度, 適切に評価できることが知られ ている，しかし，結晶粒寸法またはそれ以下のき裂は， 単軸引張圧縮状態でもせん断形の進展をすることが多 いのに加え, 微視組織の影響を大きく受けることから， それ以降のき裂と同様に取扱うことが困難である。し たがって，その境界にはあいまいさが残るが, 結晶粒 サイズ程度の微小き裂の発生とそこから試験片破損時 までの間の微小き裂の進展過程に分けて取扱うのが妥 当と思われる。また，これらはそれぞれ異なる機構で 生じ，またその全寿命に対する割合も負荷条件によっ て異なることが予想されるので, それぞれに対して 別々のパラメータを用いることが有効であると考えら

Table 1 Chemical composition of tested materials [mass\%]

\begin{tabular}{|l|c|c|c|c|c|c|c|c|}
\hline & $\mathrm{C}$ & $\mathrm{Si}$ & $\mathrm{Mn}$ & $\mathrm{Cu}$ & $\mathrm{Ni}$ & $\mathrm{Cr}$ & $\mathrm{Mo}$ & $\mathrm{N}$ \\
\hline SUS316NG & 0.012 & 0.43 & 1.41 & 0.32 & 11.53 & 17.53 & 2.19 & 0.10 \\
\hline SGV410 & 0.15 & 0.26 & 1.16 & 0.02 & 0.03 & 0.06 & 0.01 & - \\
\hline
\end{tabular}

Table 2 Summary of test conditions

\begin{tabular}{|c|c|c|c|c|c|c|}
\hline \multirow[b]{2}{*}{ Specimen } & \multirow[b]{2}{*}{$\begin{array}{c}D_{0} \\
(\mathrm{~mm})\end{array}$} & \multirow[b]{2}{*}{$\begin{array}{c}D_{i} \\
(\mathrm{~mm})\end{array}$} & \multirow[b]{2}{*}{ Loading } & \multirow[b]{2}{*}{ Control } & \multicolumn{2}{|c|}{ Number of tests } \\
\hline & & & & & $\begin{array}{c}\text { SUS } \\
316 \text { NG }\end{array}$ & $\begin{array}{l}\text { SGV } \\
410\end{array}$ \\
\hline Solid & 10.0 & - & Axial & Load & 9 & 8 \\
\hline Solid & 10.0 & - & Axial & Strain & 4 & 4 \\
\hline Hollow & 12.0 & 9.0 & Axial & Strain & 4 & 5 \\
\hline Hollow & 12.0 & 9.0 & Axial/Torsion & Strain & 3 & 3 \\
\hline Hollow & 12.0 & 9.0 & Torsion & Strain & 6 & 4 \\
\hline Hollow & 12.0 & 9.0 & Circular & Strain & 5 & 4 \\
\hline Hollow & 16.0 & 13.5 & Torsion & Load & 3 & 4 \\
\hline Hollow & 16.0 & 13.5 & $\begin{array}{c}\text { Torsion with } \\
\text { constant Tension }\end{array}$ & Load & 5 & 5 \\
\hline Solid & 13 & - & $\begin{array}{c}\text { Torsion with } \\
\text { constant Tension }\end{array}$ & Load & 12 & 5 \\
\hline Hollow & 16.0 & 14.0 & $\begin{array}{c}\text { Torsion with } \\
\text { constant Tension }\end{array}$ & Load & 6 & 5 \\
\hline & & & & & 57 & 47 \\
\hline
\end{tabular}

$D_{0}$ : Outer diameter of test section

$D_{i}$ : Inner diameter of test section
れる.ここでは, すべり変形とモード I 形のき裂進展 がそれぞれの主要メカニズムであり, 前者がせん断ひ ずみエネルギー, 後者が繰返し $J$ 積分範囲によって支 配されると考えることにより，それぞれに対して以下 のパラメータを適用する(補遺参照).

$$
\begin{aligned}
& \Delta W_{i}=\Delta \sigma_{\text {Mises }} \Delta \varepsilon_{\text {Mises }} \quad \cdots \cdots . . . \\
& \Delta W_{g}=\Delta \sigma_{\text {max }}^{2} \Delta \varepsilon_{\text {Mises }} / \Delta \sigma_{\text {Mises }}
\end{aligned}
$$

ここで, $\Delta \sigma_{\text {Mises }}, \Delta \varepsilon_{\text {Mises }}, \Delta \sigma_{\max }$ はそれぞれ Mises の 相当応力範囲, Mises の相当ひずみ範囲および最大主 応力範囲であり, 垂直応力範囲 $\Delta \sigma$, せん断応力範囲 $\Delta \tau$, 垂直ひずみ範囲 $\Delta \varepsilon$ およびせん断ひずみ範囲 $\Delta \gamma$ を用いて評価される. 以下, 本論文で新たに提案する この方法を Mises 基準の 2 パラメータ法と呼ぶ. な お，SUS304 鋼に対する澤田ら (7) の報告にあるように， 大きいせん断ひずみが繰返される場合には，最大せん 断応力の方向に沿うモード II形のき裂進展が続くこと もあるが, 本研究で対象とする $1 \%$ 以下の Mises の相 当ひずみ範囲ではモード I 形でのき裂進展が支配的で あることが多いため, モードI 形き裂進展を仮定する ことが妥当であると判断した。 なお, 純粋せん断条件 では最大主応力と最大せん断応力は等しいため, モー ドII形のき裂進展であっても $J$ 積分範囲は同じ式で 推定でき，モード I とモードIIのき裂進展特性が同等 であれば，モードIIのき裂進展も同じ式で比較的良好 に評価できる可能性がある.

一方, Mises 相当量の代わりにTresca 相当量を用 いると, 以下の Tresca 基準の 2 パラメータ法が得ら れる.

$$
\begin{aligned}
& \Delta W_{i}=\Delta \sigma_{\text {Tresca }} \Delta \varepsilon_{\text {Tresca }} \cdots \cdots \ldots . . . \\
& \Delta W_{g}=\Delta \sigma_{\max }^{2} \Delta \varepsilon_{\text {Tresca }} / \Delta \sigma_{\text {Tresca }}
\end{aligned}
$$

ここで, $\Delta \sigma_{\text {Tresca }}, \Delta \varepsilon_{\text {Tresca }}$ はそれぞれ Tresca の相当 応力範囲, 相当ひずみ範囲である.

さらにき裂発生寿命 $N_{i}$ とき裂進展寿命 $N_{g}$ がそれ ぞれのパラメータのべき乗で与えられることを仮定 し, 単軸引張圧縮条件では上記パラメータがともに $\Delta W=\Delta \sigma \Delta \varepsilon$ となることを考慮すれば，単軸疲労デー 夕より比較的容易に定数を決定できる、具体的には以 下の方法を用いた。

（i ） $N_{i} \sim 0$ と考えられる高ひずみ範囲での試験デ 一夕に対して寿命をひずみ範囲と応力範囲の積のべき 乗で近似した。なお，べき乗の指数に対しては，若干 任意性があるため, $J$ 積分範囲を用いた疲労き裂進展 則の係数 (1.6)の符号を変えた值をそのまま用いた(補 遺参照).

（ii）実際の寿命より，（i ）で得られた式から推定 される $N_{g}$ を引いたものを $N_{i}$ とみなし，この值をひ 
ずみ範囲と応力範囲の積のべき乗で近似した。

$3 \cdot 2$ 応力, ひずみの推定本手法を適用するに 当たっては, 応力, ひずみ状態を明らかにしておくこ とが必要である。平均直径 $d$, 管厚 $t$ の薄肉円筒試験 片においては，ねじりモーメント $\Delta T$ から，以下の式 でせん断応力範囲が求められる.

$$
\Delta \tau=\frac{2 \Delta T}{\pi d^{2} t}
$$

荷重制御試験でひずみが測定されていない試験に対し ては,ひずみ制御試験で得られた繰返し応力ーひずみ 関係とMises の関連流れ則を用いることによって，ひ ずみ範囲を推定した。 なお，これに際して，材料の単 軸繰返し応力範囲一ひずみ範囲関係が, ヤング率 $E$ と 塑性変形特性に関する定数 $\sigma_{y}, K, n$ を用いて, 次式 で与えられることを仮定した。

$$
\Delta \varepsilon=\frac{\Delta \sigma}{E}+\left(\frac{\Delta \sigma-2 \sigma_{y}}{K}\right)^{n}
$$

これより塑性変形が Mises の相当応力に従うとして 次式でせん断ひずみ範囲を計算した。

$$
\Delta \gamma=\frac{\Delta \tau}{G}+\sqrt{3}\left(\frac{\sqrt{3} \Delta \tau-2 \sigma_{y}}{K}\right)^{n}
$$

ここで, $G$ は横弾性係数 $[G=E / 2(1+\nu), \nu$ :ポアソ ン比である.

一方，応力が一定とみなすことができないねじりモ ーメントを受ける中実試験片に対しては，以下に示す 方法で簡易的に表面での応力，ひずみを推定した。

（i）直径 $d$ と負荷柇じりモーメント範囲 $\Delta T$ か ら, 表面での弾性せん断応力範囲を次式で求める.

$$
\Delta \tau_{e}=\frac{16 \Delta T}{\pi d^{3}}
$$

（ii） せん断ひずみ範囲を参照応力法の考え方に基

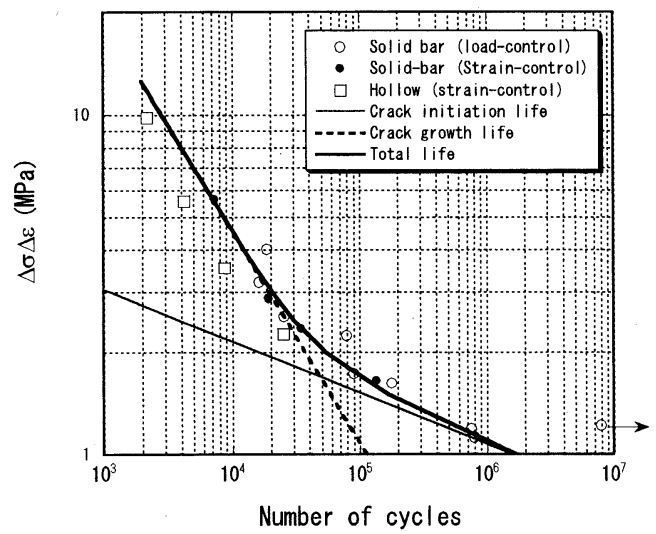

Fig. 1 Regression of uniaxial fatigue test data SUS316NG
づく以下の式で推定する.

$$
\Delta \gamma=\frac{E \Delta \varepsilon_{r e f}}{\Delta \sigma_{r e f}} \frac{\Delta \tau_{e}}{G}
$$

ここで, $\Delta \sigma_{r e f}$ は参照応力範囲, $\Delta \varepsilon_{r e f}$ は参照ひずみ範 囲で, 降伏応力 $\sigma_{0}$ の完全塑性体に対する極限モーメ ント $\left(T_{0}=\pi d^{3} \sigma_{0} / 12 \sqrt{3}\right)$ を参考にして，それぞれ以下 の式で求める.

$$
\begin{aligned}
& \Delta \sigma_{\text {ref }}=\frac{\Delta T}{T_{0}} \sigma_{0}=\frac{3}{4} \sqrt{3} \Delta \tau_{e} \ldots \ldots . \\
& \Delta \varepsilon_{\text {ref }}=\frac{\Delta \sigma_{r e f}}{E}+\left(\frac{\Delta \sigma_{r e f}-2 \sigma_{y}}{K}\right)^{n}
\end{aligned}
$$

(iii）式（9）によって得られた $\Delta \gamma$ の值に対して, 式(7)を Newton 法によって逆に解いて $\Delta \tau$ を求め る.

なお，一定軸力や曲げモーメントが重畳された試験 の評価においては, 硬化挙動への影響を通してこれら が応力, ひずみ挙動や寿命に影響を及ぼすことが推測 されるが，ここでは簡単のため，その影響は無視した。

\section{4. 評 価 結 果}

4・1 SUS316NG 鋼に対する評価 SUS316NG 鋼の引張圧縮試験で得られた単軸疲労データの破損寿 命を応力範囲とひずみ範囲の積に対してプロットし， 前述の手順に従って近似した結果を図 1 に示す。これ より, 高ひずみ領域でのこう配がき裂進展則の係数と よく一致し，試験データ全体にわたって，破損寿命 $N_{f}$ が以下の式で良好に近似できることがわかる $(\Delta \sigma$ in $\mathrm{MPa}, \Delta \varepsilon$ in $\mathrm{mm} / \mathrm{mm}$ ).

$$
\begin{aligned}
& N_{f}=N_{i}+N_{g} \ldots \ldots \ldots \ldots \ldots . \cdots \\
& N_{i}=1.58 \times 10^{6}(\Delta \sigma \Delta \varepsilon)^{-6.6} \\
& N_{g}=1.13 \times 10^{5}(\Delta \sigma \Delta \varepsilon)^{-1.6}
\end{aligned}
$$

したがって, 任意の条件下での寿命は次式で推定され るものと仮定した。

(Mises 基準の場合)

$$
\begin{aligned}
& N_{i}=1.58 \times 10^{6}\left(\Delta \sigma_{\text {Mises }} \Delta \varepsilon_{\text {Mises }}\right)^{-6.6} \ldots \ldots \ldots \ldots \\
& N_{g}=1.13 \times 10^{5}\left(\Delta \sigma_{\max }^{2} \Delta \varepsilon_{\text {Mises }} / \Delta \sigma_{\text {Mises }}\right)^{-1.6}
\end{aligned}
$$

（Tresca 基準の場合）

$$
\begin{aligned}
& N_{i}=1.58 \times 10^{6}\left(\Delta \sigma_{\text {Tresca }} \Delta \varepsilon_{\text {Tresca }}\right)^{-6.6} \ldots \ldots \ldots \\
& N_{g}=1.13 \times 10^{5}\left(\Delta \sigma_{\max }^{2} \Delta \varepsilon_{\text {Tresca }} / \Delta \sigma_{\text {Tresca }}\right)^{-1.6}
\end{aligned}
$$

繰返し応力ーひずみ関係 (寿命中期のひずみ範囲と応 力範囲の関係) を決定するために，ひずみ制御疲労試 験デー夕を Mises 相当量で整理したところ, 非比例性 が顕著な円形経路のものを除けば，狭いバンドで一致 したため, 比較的大きいひずみのデータをも含んだ中 空試験片のデー夕を式(6)で近似したものを用いた 
(図 2 中破線)。式( 6 )中の定数は以下のとおりであ る。

$$
\begin{aligned}
& E=195000 \mathrm{MPa}, \quad \sigma_{y}=137.5 \mathrm{MPa} \\
& K=1710 \mathrm{MPa}, \quad n=2.82
\end{aligned}
$$

まず, Mises ひずみ範囲を用いて引張圧縮試験での ひずみ範囲と寿命の関係から推定された寿命と実測寿 命を比較した結果を図 3 に示す。純粋せん断条件また はそれに近いものはすべて最大 50 倍程度の顕著な寿 命の過小評価が得られていることが確認できる。一 方, 非比例性が著しく高い円形ひずみ経路に対しては, 逆に寿命の過大評価が見られる。

同様に Tresca ひずみ範囲を用いた場合の結果を図

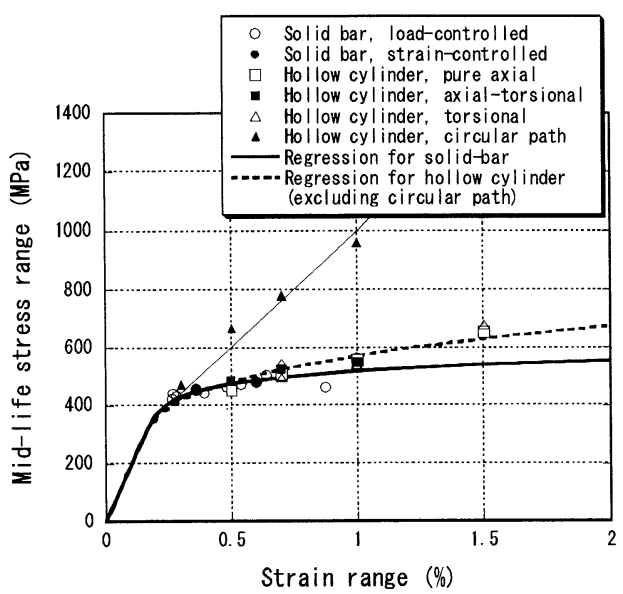

Fig. 2 Cyclic stress-strain relation of SUS316NG
4 に示す. Mises ひずみ範囲を用いた場合よりもさら に純粋せん断条件またはそれに近いものに対する保守 的傾向が増大することがわかる．また，円形ひずみ経 路に対しては，若干非保守的傾向が緩和されているが, 全般的には Mises ひずみ範囲を用いた場合と大きな 差は見られない.

Mises 基準の 2 パラメー夕法によって寿命を推定し た結果と実測寿命の比較を図 5 に示す. 図 5 から，上 記と同様に円形経路試験に対する過大評価傾向と一定 引張応力/曲げ応力負荷試験に対する過小評価傾向が 見られるものの, 推定寿命と実測寿命の差は大幅に小 さくなり, 全般的に大幅な予測精度の改善が得られて いることがわかる．特に比例負荷試験に対しては，本 手法によってファクタ 2 以内の良好な精度で寿命が推 定できていることが確認できる. なお，一定引張応力 や曲げ応力重畳の荷重制御試験の場合には, 非比例的 負荷によるひずみ範囲の減少が，寿命が過小評価され た原因と考えられる。

同様に Tresca 基準の 2 パラメー夕法による結果を 図 6 に示す. Mises 基準の場合に比心゙てやや保守性が 増大している場合もあるが, Mises 基準 2 パラメータ 法の結果と類似である.

$4 \cdot 2 \mathrm{SGV410}$ 鋼に対する評価 SGV410 鋼の引 張圧縮疲労試験で得られた単軸疲労データの破損寿命 を応力範囲とひずみ範囲の積に対してプロットした結 果を図 7 に示す.これより, SUS316NGの場合に比 べてばらつきが大きく，一意的に決定しにくいが, SUS316NG と同じ式で平均的に良好な近似ができる

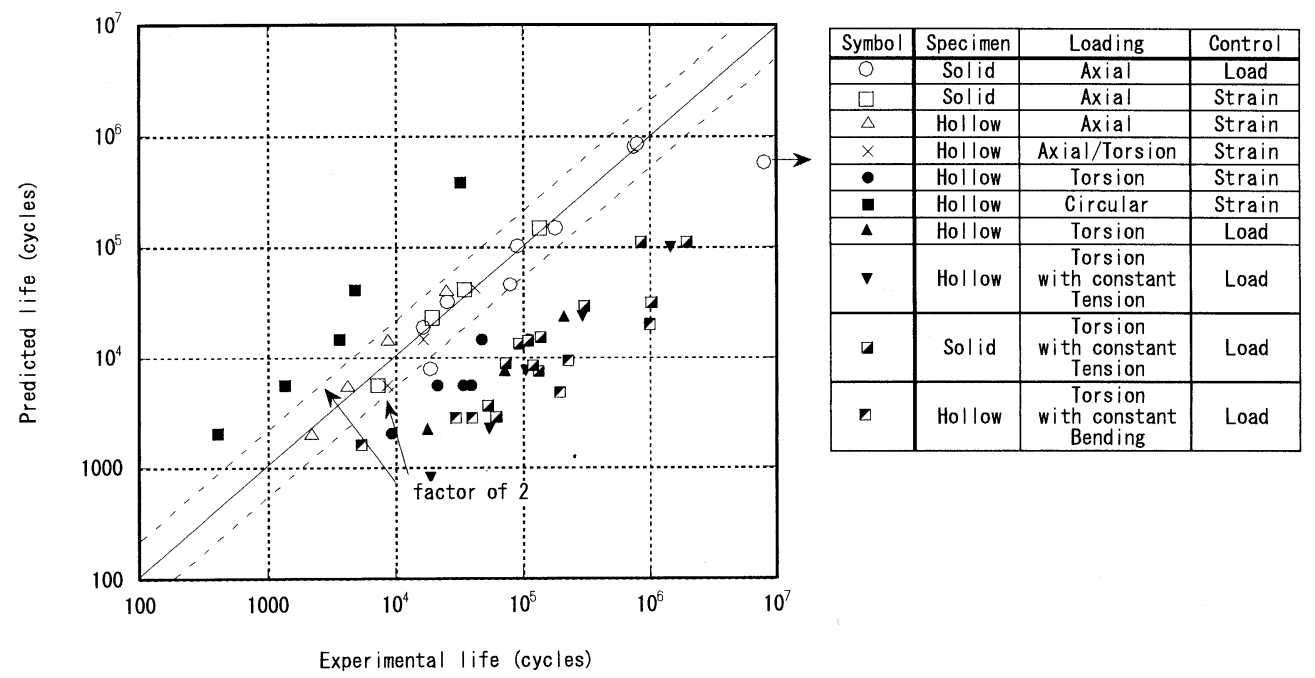

Fig. 3 Comparison between experimental life and predicted life by Mises strain range for SUS316NG 
ことが確認されるため,これを用いることとした。

繰返し応力ーひずみ関係 (寿命中期のひずみ範囲と応 力範囲の関係)については, SUS316NG の場合と同様, Mises 相当ひずみ範囲と Mises 相当応力範囲の関係 をプロットしたところ, SUS316NG ほど顕著ではな いが，円形経路試験は高くなる傾向を示し, 同様に他 の中空円筒試験結果を式（6)で近似したものを用いた (図 8 中破線). 式( 6 )中の定数は以下のと打りであ る.

$E=205800 \mathrm{MPa}, \quad \sigma_{y}=100 \mathrm{MPa}$

$K=1520 \mathrm{MPa}, \quad n=3.69$
Mises ひずみ範囲を用いて寿命を推定した結果と実 測寿命の比較を図 9 に示す. SUS316NG と同様, 円 形経路試験に対して過大予測, せん断繰返し形試験に 対して過小予測する傾向が見られるが, SUS316NG の場合に比較すると, 全般的に実測寿命と予測寿命の 間の差は小さいことがわかる.

Tresca ひずみ範井を用いて寿命を推定した結果と 実測寿命の比較を図 10 に示す. Mises ひずみ範囲に よる推定結果とさほど大きく変わらないことがわか る.

Mises 基準, Tresca 基準の 2 パラメータ法によっ

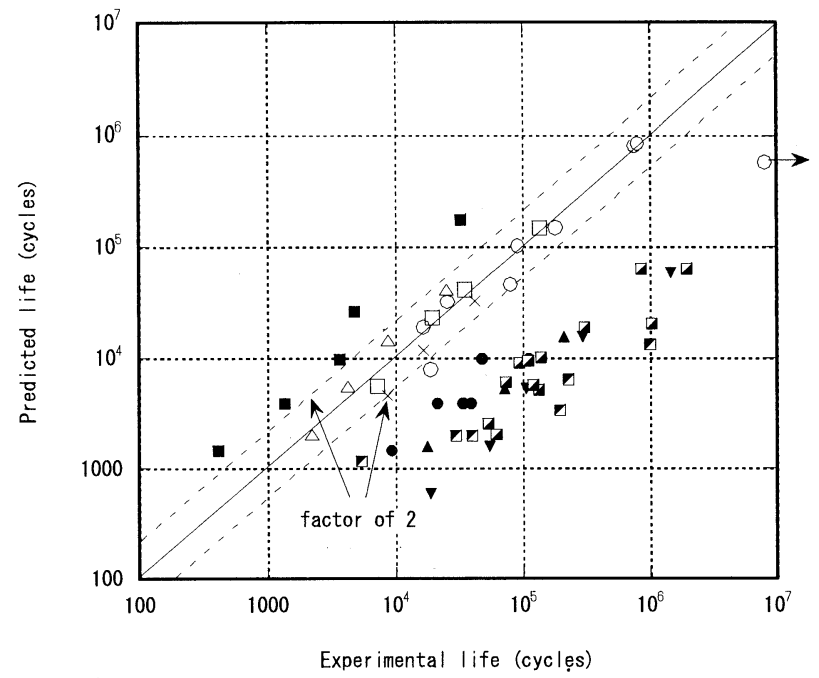

\begin{tabular}{|c|c|c|c|}
\hline Symbol & Specimen & Loading & Control \\
\hline 0 & Solid & Axial & Load \\
\hline$\square$ & Solid & Axial & Strain \\
\hline$\Delta$ & Hollow & Axial & Strain \\
\hline$\times$ & Hollow & Axial/Torsion & Strain \\
\hline$\bullet$ & Hollow & Torsion & Strain \\
\hline$\square$ & Hollow & Circular & Strain \\
\hline$\Delta$ & Hollow & Torsion & Load \\
\hline$\nabla$ & Hollow & $\begin{array}{c}\text { Torsion } \\
\text { with constant } \\
\text { Tension }\end{array}$ & Load \\
\hline$\square$ & Sol id & $\begin{array}{c}\text { Torsion } \\
\text { with constant } \\
\text { Tension }\end{array}$ & Load \\
\hline & $\begin{array}{c}\text { Torsion } \\
\text { with constant } \\
\text { Bending }\end{array}$ & Load \\
\hline
\end{tabular}

Fig. 4 Comparison between experimental life and predicted life by Tresca strain range for SUS316NG

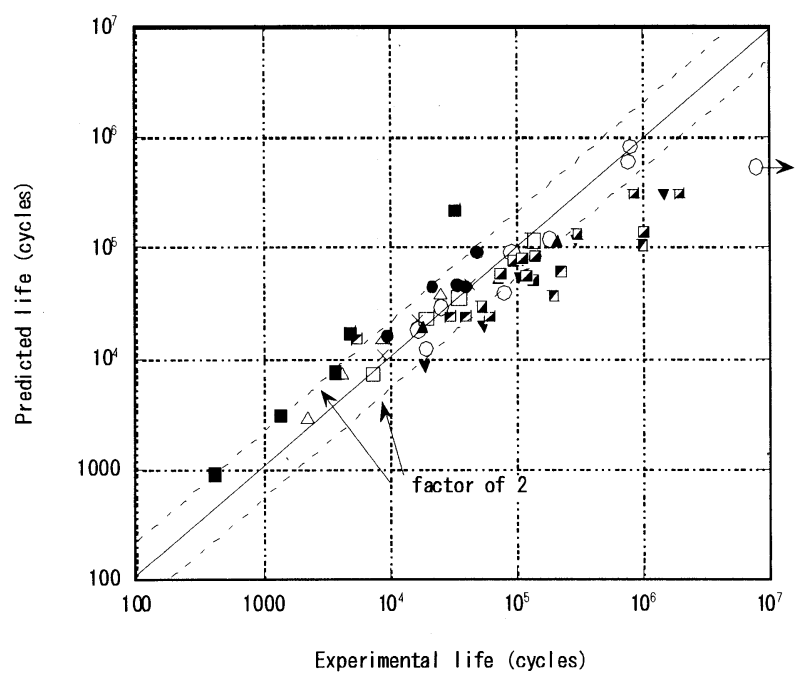

\begin{tabular}{|c|c|cc|}
\hline Symbol & Specimen & Loading & Control \\
\hline 0 & Solid & Axial & Load \\
$\square$ & Solid & Axial & Strain \\
$\Delta$ & Hol low & Axial & Strain \\
\hline$\times$ & Hol low & Axial/Torsion & Strain \\
\hline$\bullet$ & Hol low & Torsian & Strain \\
\hline$\square$ & Hol low & Circular & Strain \\
\hline$\Delta$ & Hol low & Torsian & Load \\
\hline$\nabla$ & Hollow & $\begin{array}{c}\text { Torsian } \\
\text { with constant } \\
\text { Tensian }\end{array}$ & Load \\
\hline$\square$ & Sol id & $\begin{array}{c}\text { Torsian } \\
\text { with constant } \\
\text { Tensian }\end{array}$ & Load \\
\hline$\square$ & Hol low & $\begin{array}{c}\text { Torsian } \\
\text { with constant } \\
\text { Bending }\end{array}$ & Load \\
\hline
\end{tabular}

Fig. 5 Comparison between experimental life and predicted life by Mises-based two parameter approach for SUS316NG 


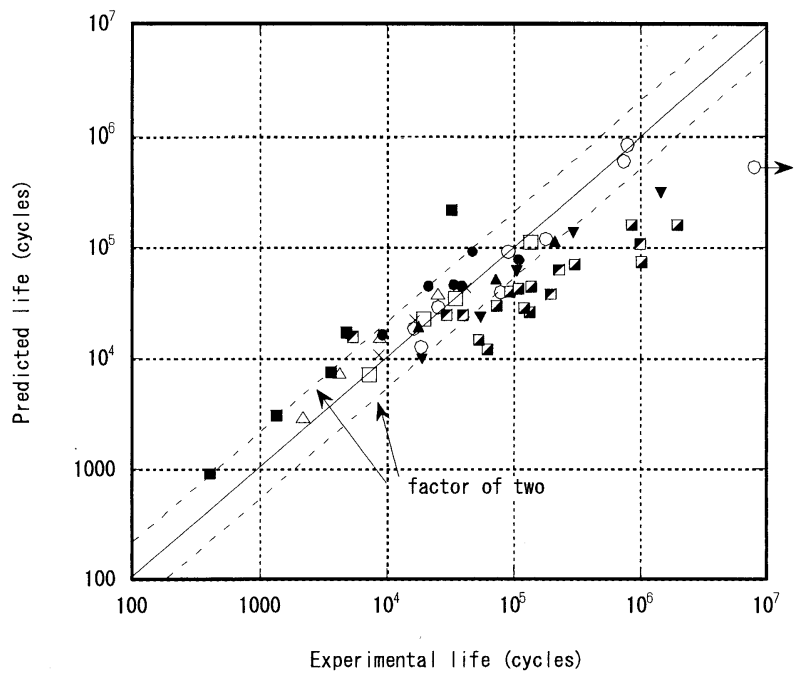

\begin{tabular}{|c|c|c|c|}
\hline Symbol & Specimen & Loading & Control \\
\hline 0 & Solid & Axial & Load \\
\hline$\square$ & Solid & Axial & Strain \\
\hline$\Delta$ & Hollow & Axial & Strain \\
\hline$\times$ & Hollow & Axial/Torsion & Strain \\
\hline$\bullet$ & Hollow & Torsion & Strain \\
\hline$\square$ & Hollow & Circular & Strain \\
\hline$\Delta$ & Hol low & Torsion & Load \\
\hline$\nabla$ & Hollow & $\begin{array}{c}\text { Torsion } \\
\text { with constant } \\
\text { Tension }\end{array}$ & Load \\
\hline$\square$ & Solid & $\begin{array}{c}\text { Torsion } \\
\text { with constant } \\
\text { Tension }\end{array}$ & Load \\
\hline$\square$ & $\begin{array}{c}\text { Torsion } \\
\text { Hith constant } \\
\text { Bending }\end{array}$ & Load \\
\hline
\end{tabular}

Fig. 6 Comparison between experimental life and predicted life by Tresca-based two parameter approach for SUS316NG

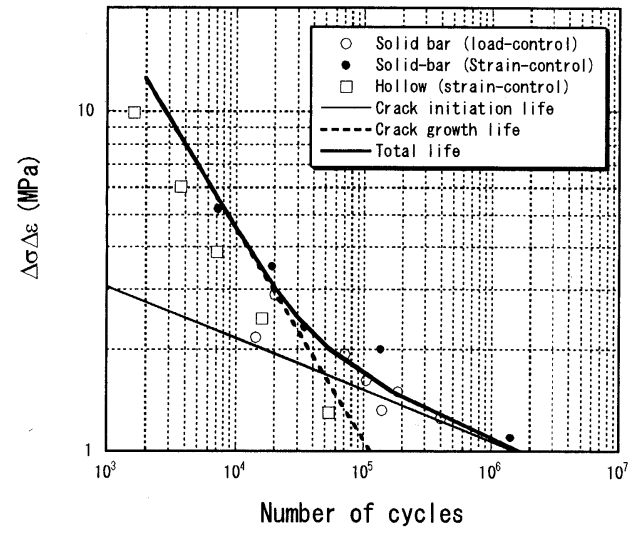

Fig. 7 Regression of uniaxial fatigue data of SGV410

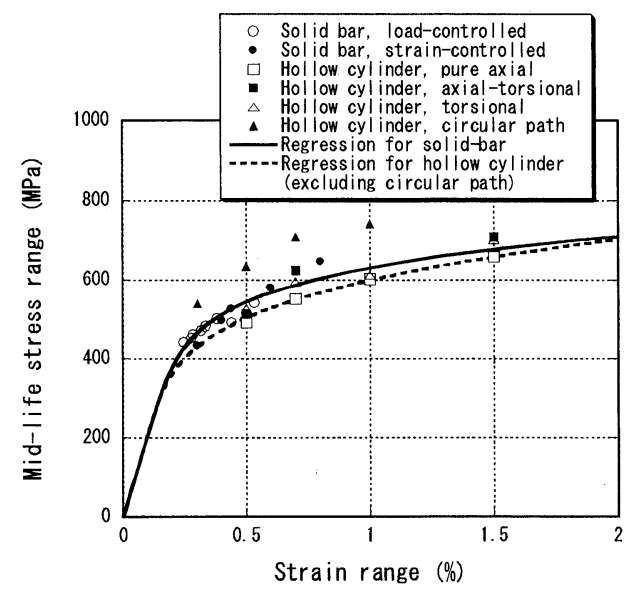

Fig. 8 Comparison of cyclic stress-strain relations of SGV410

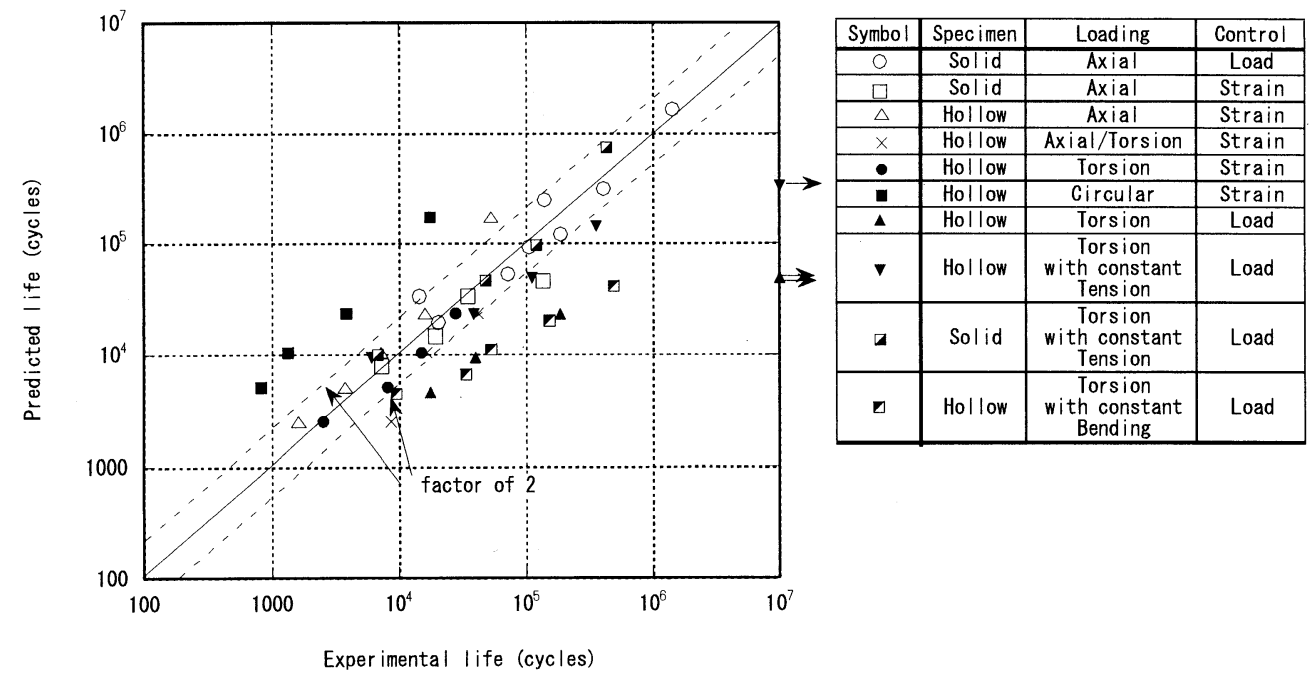

Fig. 9 Comparison between experimental life and predicted life by Mises strain range for SGV410 
て寿命を推定した結果と実測寿命の比較を図 11,12 に示す．両者の間に大きな差はなく，ばらつきも少な いが，ねじりを含んだ多くの中空円筒試験や一定軸応 力を重畳させた中実円筒試験では寿命を過大推定する 傾向が生じている.

\section{5. 考察}

以上より，ステンレス鋼の場合には最大主応力範囲 を導入することによって, 多軸疲労寿命評価の高精度 化が可能となる見通しが得られた，ただし，本研究に おける試験はすべて主応力比(試験片表面に平行な主
応力のうち, 小さいものを大きいもので割った值)が 0 以下の条件で実施されているため, 主応力比が正の条 件に対する適用性を検討することが必要である。図 13 に最大主応力範囲と Mises 相当応力範囲の比, $\Delta \sigma_{\max } / \Delta \sigma_{\text {Mises }}$ の主応力比に対する依存性を示す。こ れより, 主応力比が正の条件ではこの值は 1 よりも若 干大きくなり, 新しいクライテリオンに従えば寿命が 単軸状態よりも短くなることも予測される.

図 14 は, 各主応力比に対して, $\Delta \sigma_{\text {Mises }} \Delta \varepsilon_{\text {Mises }}$ を用 いた疲労曲線を作成した結果を示す。疲労曲線は主応 力比 0.5 のときに最短となるが，単軸条件に対する寿

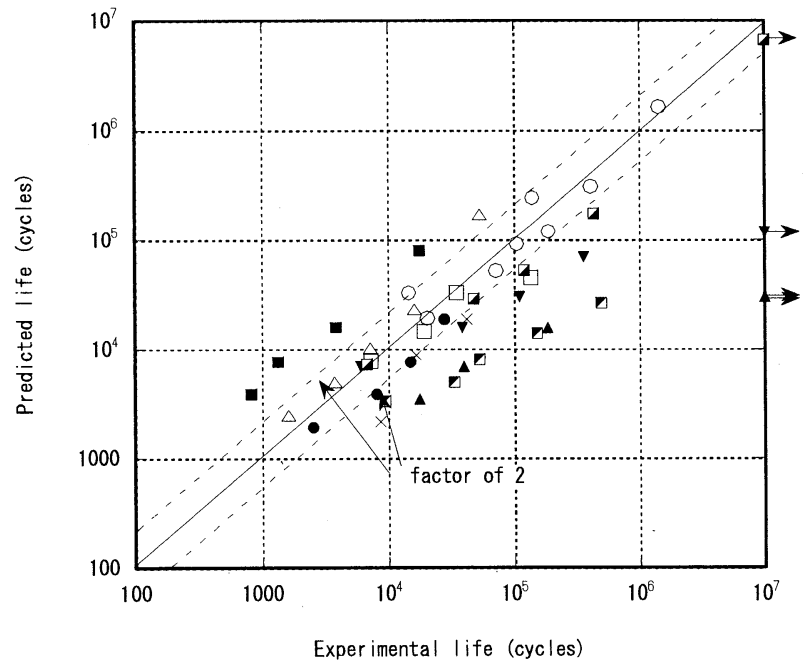

\begin{tabular}{|c|c|c|c|}
\hline Symbol & Specimen & Loading & Control \\
\hline 0 & Solid & Axial & Load \\
\hline$\square$ & Solid & Axial & Strain \\
\hline$\Delta$ & Hollow & Axial & Strain \\
\hline$\times$ & Hollow & Axial/Torsion & Strain \\
\hline$\bullet$ & Hollow & Torsion & Strain \\
\hline $\mathbf{\square}$ & Hollow & Circular & Strain \\
\hline $\mathbf{\Delta}$ & Hollow & Torsion & Load \\
\hline $\mathbf{\square}$ & Hollow & $\begin{array}{c}\text { Torsion } \\
\text { with constant } \\
\text { Tension }\end{array}$ & Load \\
\hline$\square$ & Hol id & $\begin{array}{c}\text { Torsion } \\
\text { with constant } \\
\text { Tension }\end{array}$ & Load \\
\hline $\begin{array}{c}\text { Torsion } \\
\text { with constant } \\
\text { Bending }\end{array}$ & Load \\
\hline
\end{tabular}

Fig. 10 Comparison between experimental life and predicted life by Tresca strain range for SGV410

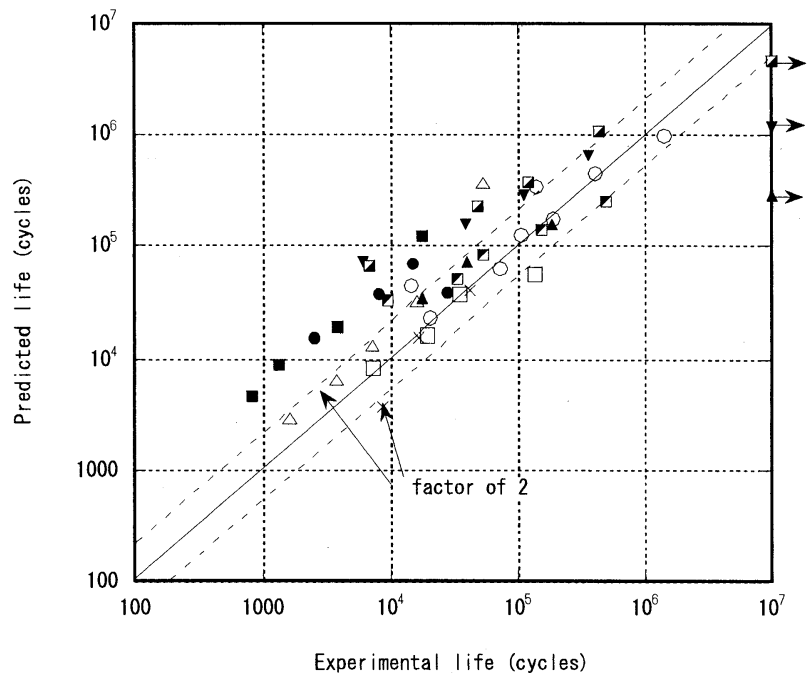

\begin{tabular}{|c|c|c|c|}
\hline Symbol & Specimen & Loading & Control \\
\hline 0 & Solid & Axial & Load \\
\hline$\square$ & Solid & Axial & Strain \\
\hline$\Delta$ & Hollow & Axial & Strain \\
\hline$\times$ & Hollow & Axial/Torsion & Strain \\
\hline$\bullet$ & Hollow & Torsion & Strain \\
\hline$\square$ & Hollow & Circular & Strain \\
\hline $\mathbf{\square}$ & Hollow & Torsion & Load \\
\hline $\mathbf{v}$ & Hollow & $\begin{array}{c}\text { Torsion } \\
\text { with constant } \\
\text { Tension }\end{array}$ & Load \\
\hline $\mathbf{D}$ & Hol id & $\begin{array}{c}\text { Torsion } \\
\text { with constant } \\
\text { Tension }\end{array}$ & Load \\
\hline $\begin{array}{c}\text { Torsion } \\
\text { with constant } \\
\text { Bending }\end{array}$ & Load \\
\hline
\end{tabular}

Fig. 11 Comparison between experimental life and predicted life by Mises-based two parameter approach for SGV410 


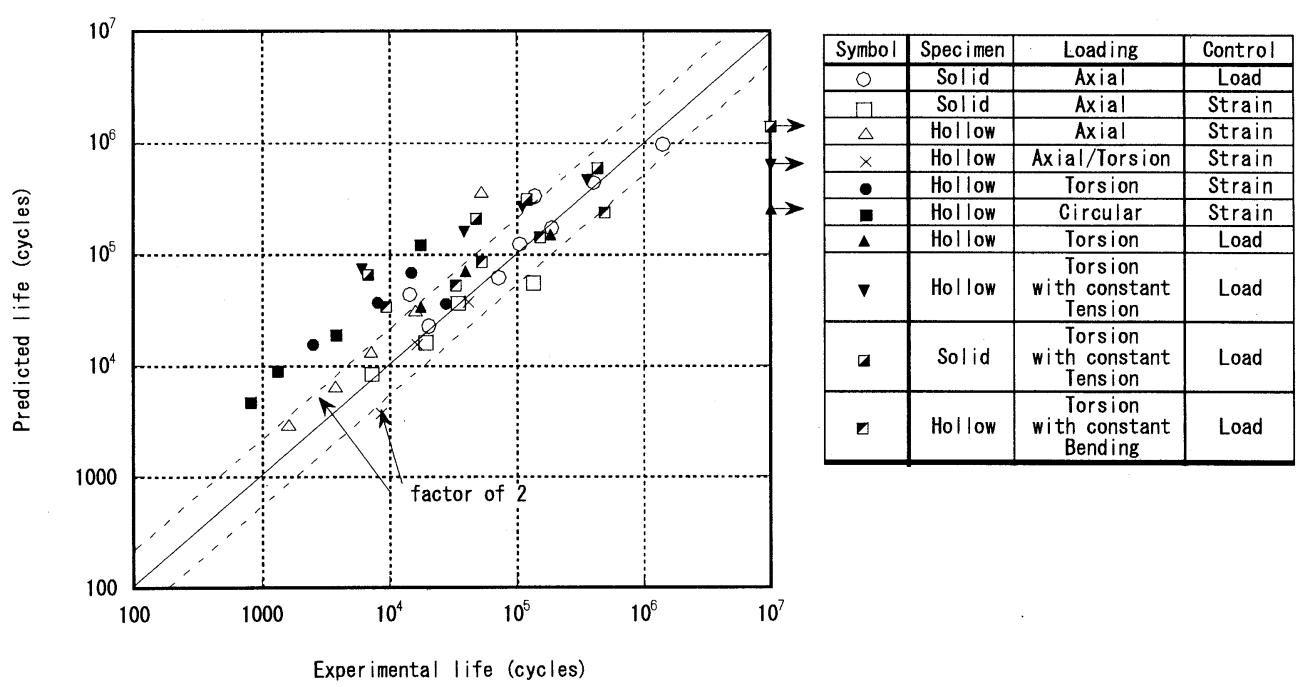

Fig. 12 Comparison between experimental life and predicted life by Tresca-based two parameter approach for SGV410

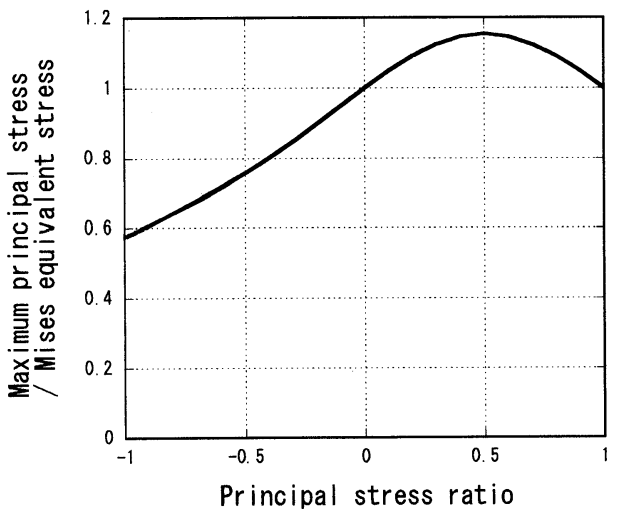

Fig. 13 Relation between principal stress ratio and $\Delta \sigma_{\max } / \Delta \sigma_{\text {Mises }}$

命比は $1 / 1.6$ 程度であり, 現在の設計基準で適用され ている寿命に対する安全係数 20 を考慮すると, Mises 相当ひずみ範囲によって評価することによって保守性 を損ねる可能性は小さいものと判断される.なお，現 行基準でより広く用いられている Tresca 基準の場合 には正の主応力比の領域では最大主応力範囲と等しい ため, 問題にはならない.

なお, SUS316NG と SGV410に対する評価結果に 見られた差異の原因は不明であり，その解明のために はさらなる検討が必要である。

\section{6. 結 言}

2 種の原子力プラント配管材料に対する多軸疲労試

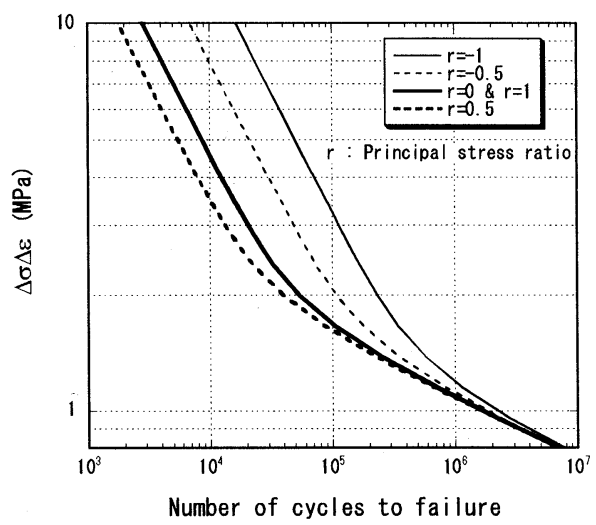

Fig. 14 Comparison of fatigue curves at different principal stress ratio

験の結果を基に, 多軸疲労評価法に関する検討を行っ た. 得られたおもな知見は以下のとおりである.

（1）現行設計基準で使用されている Mises 相当 ひずみ範囲や Tresca 相当ひずみ範囲は極めて非比例 性が高い円形経路試験を除き，寿命を保守的に推定す ることが確認された。

（2）これらが顕著な保守性を与えることの多い SUS316NG に対しては, 微小き裂発生寿命と微小き 裂進展寿命の分離に基づいた 2 パラメータ法が代替法 として有効であることが確認された。

（3） 2 パラメー夕法は SGV410 では若干非保守的 になる傾向が見られたため, 保守性確保の観点からは 逆に若干保守的になるきらいがある Mises 相当ひず 
み範囲基準のほうが望ましいと考えられる。

本研究は, 東京電力 (株), 北海道電力 (株), 東北電 力 (株), 中部電力 (株), 北陸電力 (株), 関西電力(株), 中国電力 (株), 四国電力 (株), 九州電力 (株), 日本原 子力発電(株), 電源開発(株) からの委託研究として (社) 日本溶接協会原子力研究委員会 MF-II 小委員会 で行われたものの一部である. 主査の矢川元基東洋大 学教授はじめ, ご議論いただいた委員各位に感謝の意 を表する。

\section{補遺：き裂進展パラメータの導出}

弾塑性状態での疲労き裂進展速度は以下のように繰 返し $J$ 積分範囲のべき乗によって支配されることが 広く知られている ${ }^{(8)}$.

$$
\frac{\mathrm{d} a}{\mathrm{~d} N}=\alpha(\Delta J)^{m}
$$

ここで, $\alpha$ と $m$ は材料定数である. 繰返し $J$ 積分範 囲は構造物の形状や負荷のほか, き裂形状・寸法の関 数であるが，参照応力法(9) を用いれば，下記の式で簡 易的に推定できる.

$$
\Delta J=\frac{\Delta \varepsilon_{\text {ref }}}{\Delta \sigma_{\text {ref }}} \Delta K^{2}
$$

ここで $\Delta K$ は応力拡大係数範囲であり，き裂寸法を表 すパラメータ $a$ とその関数である形状補正係数 $f(a)$ を用いて, 次式で評価できる.

$$
\Delta K=\Delta \sigma_{\max } \sqrt{\pi a} f(a)
$$

一方, $\Delta \sigma_{r e f}$ は参照応力で, 一様な応力中の微小き裂 に対しては,

$$
\Delta \sigma_{\text {ref }} \approx \Delta \sigma_{\text {Mises }}
$$

が成立する。これらを総合すると，

$$
\Delta J=\frac{\Delta \varepsilon_{\text {Mises }}}{\Delta \sigma_{\text {Mises }}}\left[\Delta \sigma_{\max } \sqrt{\pi a} f(a)\right]^{2}
$$

が得られる。ここで, 式(19)を考慮し，き裂が $a_{0}$ から $a_{f}$ まで成長する期間を微小き裂進展寿命であると考 えれば,

$$
N_{g}=\left[\frac{\int_{a_{0}}^{a_{f}} \frac{\mathrm{d} a}{\pi a[f(a)]^{2}}}{\frac{\Delta \varepsilon_{\text {Mises }}}{\Delta \sigma_{\text {Mises }}}\left(\Delta \sigma_{\text {max }}\right)^{2}}\right]^{m}
$$

ここで, 括弧内の分子が負荷条件によらないことか 5,

$$
N_{g}=k\left[\frac{\Delta \varepsilon_{\text {Mises }}}{\Delta \sigma_{\text {Mises }}}\left(\Delta \sigma_{\max }\right)^{2}\right]^{-m}
$$

が導かれる.括弧内が式（2）の $\Delta W_{g}$ の表現式であ る. Misesの降伏条件の代わりに Tresca の降伏条件 を用いると, 同様にして式 (4)が得られる.

\section{文献}

(1) American Society of Mechanical Engineers, Boiler and Pressure Vessel Code, Section III (2007).

(2) American Society of Mechanical Engineers, Boiler and Pressure Vessel Code, Section XI (2007).

(3) American Society of Mechanical Engineers, Boiler and Pressure Vessel Code, Section VIII, Division 2 (2007).

(4) Brown, M. W. and Miller, K. J., Fatigue of Engineering Materials and Structures, Vol. 1 (1979), p. 217.

(5) Kandil, F. A. et al., Proceedings of International Conference on Mechanical Behaviour and Nuclear Application of Stainless Steel at Elevated Temperatures, (19815), p. 203.

(6) Itoh, T. et al., Transactions of ASME, Journal of Engineering Materials Technology, Vol. 116 (1994), p. 90.

(7) Sawada, M. et al., Journal of the Society of Materials Science, Japan, Vol. 54 (2005), p. 615.

(8) Takahashi, Y. et al., Transactions of 17th Interna tional Conference on Structural Mechanics in Reactor Technology, (2007), paper No. G 11-7.

(9) Ainsworth, R.A., Engineering Fracture Mechanics, Vol. 19 (1984), p. 633. 